\title{
Measuring the Hedge Ratio: A GCC Perspective
}

\author{
Ahmad Bash ${ }^{1}$, Abdullah M. Al-Awadhi ${ }^{1}$ \& Fouad Jamaani ${ }^{1}$ \\ ${ }^{1}$ School of Economics, Finance and Marketing, RMIT University, Australia \\ Correspondence: Ahmad Bash, School of Economics, Finance and Marketing, RMIT University, Melbourne VIC \\ 3000, Australia. Tel: 61-447-718-868. E-mail: ahmad.bash@rmit.edu.au \\ Received: March 29, 2016 \\ Accepted: April 16, 2016 \\ Online Published: June 25, 2016 \\ doi:10.5539/ijef.v8n7p1 \\ URL: http://dx.doi.org/10.5539/ijef.v8n7p1
}

\begin{abstract}
In this paper, we examine the effectiveness of minimising the variance of the hedge ratio using different econometric models for the GCC currencies under money-market hedging and cross-currency hedging. Specifically, we determine whether different model specifications and estimation methods yield different hedge-effectiveness results. In other words, does the sophistication of the model improve the effectiveness of the hedge? Our results show that these econometric models fail either to add value or to improve the effectiveness of the hedge.
\end{abstract}

Keywords: Gulf Co-operation Council (GCC), risk-minimizing hedge ratio, money-market hedging, cross-currency hedging

\section{Introduction}

After the collapse of the Bretton Woods system and the introduction of flexible exchange rates in the early 1970s - coupled with the tendency of firms to engage in international business - the need has arisen to pay attention to fluctuations in exchange rates. Exchange-rate volatility affects not only firms that operate in international markets, but also domestic firms that compete with other firms that import goods from abroad, as well as purely domestic firms such as utility providers. In other words, even domestic firms that operate in the local market are affected by currency fluctuations (Adler \& Dumas, 1984; Aggarwal \& Harper, 2010).

This paper is concerned with the management of foreign-exchange risk from the perspective of a domestic firm operating in a member country of the Gulf Co-operation Council (GCC). This is a bloc of countries in the Middle East that includes Kuwait, Kingdom of Saudi Arabia (KSA), United Arab Emirates (UAE), Bahrain, Qatar, and The Sultanate of Oman. Apart from Kuwait, which pegs its currency to a basket of currencies, all of these countries adopt a fixed exchange-rate regime in which they peg their currencies to the US dollar. While a policy of pegging to the dollar keeps the exchange rate against the dollar stable, the exchange rates against other currencies remain volatile. Since these countries trade more with the European Union, Japan, and China than with the United States, exposure to foreign-exchange risk is a major issue of concern for businesses using one of the GCC currencies as a base currency. Given that these countries also lack sophisticated financial markets, hedging exposure to foreign-exchange risk becomes a rather challenging task.

Researchers have been widely estimating the hedge ratio using the ordinary least squares (OLS) estimation method. However, in the financial-econometrics literature, there are many other estimation methods that can be used to estimate the hedge ratio empirically apart from OLS. In this paper, we examine the effectiveness of minimising the variance of the hedge ratio using different econometric models for the GCC currencies under money-market hedging and cross-currency hedging. The purpose of this paper is to determine whether different model specifications and estimation methods yield different hedge-effectiveness results. In other words, does the sophistication of the model improve the effectiveness of the hedge? Our results show that these econometric models fail either to add value or to improve the effectiveness of the hedge. The results from this paper may be beneficial for the managers of firms engaged in international trade, as well as researchers interested in foreign-exchange risk management. In addition, the results will add value to those agents who employ hedging techniques using the currencies of developing countries that lack sophisticated financial markets. This paper starts with a literature review in Section 2, followed by discussion of the methodology in Section 3, data and empirical results are in Section 4 and the conclusion is in Section 5. 


\section{Literature Review}

Firms that are involved in international-business transactions should always employ the best model to estimate the optimal hedge ratio. A perfect hedge in which the loss (profit) in the unhedged position is completely offset by the profit (loss) in the hedged position may not occur in real-life situations. (Note 1) Therefore, firms will have greater concern about minimising the variance of the rate of return in the hedged position to avoid the adverse effect of exchange-rate changes. The estimation of a minimum-variance hedge ratio depends on the econometric model employed to estimate it (Ghosh, 1993). According to Wang et al. (2015), given that numerous sophisticated estimation methods have been utilised aside from OLS estimation to estimate the hedge ratio, the best estimation method is still unclear. However, Lence (1995), Lien et al. (2002), and Moosa (2011) find that using a simple econometric model to estimate the hedge ratio can provide similar results to those obtained with sophisticated ones. Alexander and Barbosa (2007) find that neither a complex model (such as time-varying conditional covariance), nor the error-correction model (ECM) can outperform the simple OLS model. Copeland and Zhu (2006) and Alexander and Barbosa (2007) also argue that there is no value added when using a sophisticated model to estimate the hedge ratio compared with simple OLS. In fact, according to Moosa (2003a), the success and failure of estimating hedging effectiveness depends on the correlation between the price of the unhedged position and the price of the hedged instrument, not on model specifications.

According to Ederington (1979), the relationship between cash price and future price is represented by a regression model, and a slope coefficient represents the hedge ratio with the objective of minimising the risk of the portfolio (risk-minimising hedge ratio). From a theoretical point of view, this optimal hedge ratio with the objective of minimising the variance of the hedged portfolio is a form of an expected-utility maximisation framework (Johnson, 1960; Ederington, 1979; Myers \& Thompson, 1989, Lien \& Tse, 2002). This minimum-variance framework is widely used because it is simple to compute and easy to understand (Chen et al., 2003).

The first problem is related to model specification. The conventional OLS model that uses levels or changes in the exchange rates (the unhedged asset such as a spot rate being a dependent variable and the hedged asset such as a forward or futures rate being the independent variable) has been widely used in the literature (Ederington, 1979; Junkus \& Lee, 1985; Malliaris \& Urrutia, 1991; Benet, 1992). However, the problem arises in determining which of the specifications (price level or price change) is more appropriate than the other to estimate the hedge ratio. For example, Witt et al. (1987) support the price-level model, whereas Hill and Schneeweis (1981) and Wilson (1983) support the price-change (return) model. Ghosh $(1993,1995,1996)$ argues that these methods are misspecified, as using a price-level hedge ratio ignores short-term dynamics, whereas using a price-changes (return) hedge ratio ignores long-term relationships. Ghosh added an error-correction term to improve the model, as the first-difference model ignores the long-term relationship implied by the error-correction term. In addition, he argues that the omission of a cointegration relationship between variables (spot and forward rates) represented by the error-correction term produces a smaller hedge ratio than the optimal ratio. Lien (1996) was the first to prove this mathematically by showing that when estimating the hedge ratio using a first-difference model, agents will be under-hedged.

The use of the ECM of Engle and Granger (1987) for estimating the optimal hedge ratio for corn, soybeans, and wheat is found in Myers and Thompson (1989). Moreover, Chou et al. (1996) find that hedging under the ECM model outperforms the conventional model for Nikkei spot and futures indices. In the literature, OLS is criticised as being inappropriate to use in estimating the hedge ratio, due to the serial correlation and heteroskedasticity in the error term arising from the relationship between spot and forward rates (Hill \& Schneeweis, 1981; Herbst et al., 1993; Kenourgios et al., 2008).

The second problem that arises in the literature relates to the dynamics of the hedge ratio. It is associated with the view of whether the hedge ratio is constant or changing over time and the question of whether a conditional or unconditional probability distribution (moments) should be used to estimate it. (Note 2) For example, the static hedge ratio based on unconditional moments has been studied by Ederington, (1979), Howard and D'Antonio (1984), Benet (1992), Ghosh (1993, 1995, 1996), and Kolb and Okunev (1992, 1993). Alternatively, a dynamic (changing) hedge ratio based on conditional moments such as the ARCH and GARCH family of models - in which it is assumed that covariance and variance of returns are time-varying - has been studied in Cecchetti et al. (1988), Baillie and Myers (1991), Kroner and Sultan (1993), Sephton (1993), Brooks and Chong (2001), Hatemi-J and Roca (2006), Park and Jei (2010), and Hatemi-J and El-Khatib (2012). However, time-varying models also receive criticism, as they introduce too much noise that affects cost-effective hedges (Copeland \& Zhu, 2006; Alexander \& Barbosa, 2007). 
In this paper, we do not investigate this dynamic aspect of the hedge ratio; instead, the scope is limited to comparing different empirical-model specifications and estimation methods that minimise the variance of the hedge ratio, as in Moosa (2011), who shows that financial-econometrics models used to estimate the hedge ratio fail to add value in improving the effectiveness of the hedge. (Note 3) Therefore, he suggests that a naïve hedge ratio of 1 provides similar results to the sophisticated econometric models. The inferences that Moosa obtains suggest that the dominance of the naïve hedge ratio are consistent with those of Jong et al. (1995), Jong et al. (1997), Grant and Eaker (1989), Maharaj et al. (2008), Alexander et al. (2013), and Wang et al. (2015). (Note 4).

\section{Methodology}

Money-market hedging is based on the covered interest parity (CIP) condition, which suggests that the difference between the spot and the forward rate is related to the interest-rate differential between two countries. CIP implies that a high-interest currency sells at a forward discount, and a low-interest currency sells at a forward premium. In an efficient market in which transaction costs are absent, the interest-rate differential is equal to the forward spread as equilibrium is achieved in the money market (Shapiro, 2010). CIP confirms that the return on unhedged local interest-rate investment and hedged foreign-currency investment will be equal. Therefore, the return differential becomes zero. When such a condition does not hold, an arbitrage opportunity arises by borrowing one currency and investing in the other.

Money-market hedging consists of borrowing in the domestic currency and lending in the foreign currency, or vice versa, to cover expected receivables and payables. This process creates an implicit forward rate $\bar{F}$ (the price of a synthetic forward contract). Therefore, the forward contract can be replicated by money-market hedging, given that CIP holds (Khoury \& Chan, 1988). Given that the base currency is $x$ and the foreign currency is $y$, we can use money-market hedging for payables and receivables as follows. Suppose that a firm has payables of $K$ in foreign currency y due at time $t+1$ :

1) At time $t$, the company borrows the present value of amount $K$ discounted at foreign interest rate $i^{*}$ from a local bank in the domestic currency. This is $K S_{t} /\left(1+i^{*}\right)$.

2) The domestic-currency amount is then converted into the foreign currency $y$ at $S_{t}$ (to obtain the present value of the foreign currency payable) that will be invested at $i^{*}$. The amount from this investment is used to cover the payables due at $t+1$.

3) At $t+1$, the domestic-currency loan becomes due, so the firm should repay the principal and interest $K S_{t}$ $(1+i) /\left(1+i^{*}\right)$.

4) Given that we pay $K S_{t}(1+i) /\left(1+i^{*}\right)$ units of $x$ to obtain $K$ units of $y$, hence, the implicit forward rate is

$$
\bar{F}_{t}=\frac{K S_{t}(1+i) /\left(1+i^{*}\right)}{K}=S_{t}(1+i) /\left(1+i^{*}\right)
$$

From the above operations, no matter what value $S_{t+1}$ is, the firm realises in advance the domestic-currency value of payables because they will act on $\bar{F}_{t}$. Therefore, the firm knows in advance how much they will pay in the case of payables, and if $\bar{F}_{t}<S_{t+1}$, this means that the uncovered interest-rate parity $\left(\bar{F}_{t}=S_{t+1}\right)$ has been violated and the hedge decision will be the best decision. However, if $\bar{F}_{t}>S_{t+1}$, no hedge will be the best decision. Finally, if $\bar{F}_{t}=S_{t+1}$, the decision on whether to hedge or not to hedge will yield the same result. When we compare the implicit forward rate with the forward rate, if $\bar{F}<F$, this means that a money-market hedge is better than a forward hedge and CIP does not hold. However, if $F=\bar{F}$, then CIP holds and there is no difference between hedging by forward contract and hedging by the money market. One should note that money-market hedging consists of many transactions and could be costly. Therefore, it should only be used if there is no forward contract.

In terms of receivables, we would have the same operations except that the decision would be the opposite. The firm knows in advance how much they will receive, and if $\bar{F}_{t}<S_{t+1}$, this means that the uncovered interest-rate parity $\left(\bar{F}_{t}=S_{t+1}\right)$ has been violated and the no-hedge decision will be the best decision. However, if $\bar{F}_{t}>S_{t+1}$, hedging will be the best decision. Finally, if $\bar{F}_{t}=S_{t+1}$, the decision on whether to hedge or not to hedge will yield the same result. Table 1 summarises the money-market hedging decision for both payables and receivables. 
Table 1. Money-market hedging decision for both payables and receivables

\begin{tabular}{lll}
\hline Price condition & In the case of payables & In the case of receivables \\
\hline $\bar{F}_{t}<S_{t+1}$ & Hedge & Not to hedge \\
$\bar{F}_{t}>S_{t+1}$ & Not to hedge & Hedge \\
$\bar{F}_{t}=S_{t+1}$ & Same result & Same result \\
\hline
\end{tabular}

Source: Moosa (2003b).

Al-Loughani and Moosa (2000) find that there is no difference between hedging by forward contract and hedging by money-market hedge when they examine whether the CIP holds or not indirectly. They find that the CIP does hold and these two hedging techniques are equivalent to each other, as both of them reduce the variability of the return.

Cross-currency hedging can be implemented by either taking a position on another foreign-currency derivative or another foreign-currency spot rate. When a derivative instrument such as a forward or an option is unavailable for a certain foreign currency $y$, the firm can take the position of buying or selling a derivative for another foreign currency $z$, which has an exchange rate against the domestic currency $F(x / z)$, that is correlated with the original exchange rate $S(x / y)$. For example, if company A has foreign exposure of currency y but there is no derivative instrument for currency $y$, then this firm can take a position of buying or selling derivatives for the $z$ currency, based on the strong correlation between $S(x / y)$ and $F(x / z)$.

Another technique for cross-currency hedging instead of using currency derivative is when the firm takes a spot position on another foreign currency $z$. For example, suppose that a firm has a short position on currency $y$, it can hedge the position by taking a long position on a third currency $z$ (given that the foreign-currency exchange rate $S(x / y)$ and the third-currency exchange rate $S(x / z)$ are highly correlated), and vice versa. For example, if a firm has payables (short position) in currency $y$, it can buy (long position) currency $z$. Therefore, if currency $y$ appreciates, the third-currency exchange rate $S(x / z)$ will also rise, which means that the loss that would occur from currency $y$ is offset by the profit from currency $z$. This technique relies on the spot market, not the forward market. Schwab and Lusztig (1978) argue that if the transacting partners aim to minimise the risk and their concern is a nominal return and cost, a mix of the two currencies for the two parties should be used; if the concern is the real return and cost based on the reference basket, a third currency should be used.

As stated above, we follow Moosa (2011) in estimating the optimal hedge ratio. We use nine different econometric models for comparison. After that, we measure the effectiveness of the hedge ratio by examining the effectiveness of the no-hedge decision against the hedge decision where we test the equality of variances for the returns under each position.

$$
\begin{aligned}
& H_{0}: \sigma^{2}\left(R_{U}\right)=\sigma^{2}\left(R_{H}\right) \\
& H_{a}: \sigma^{2}\left(R_{U}\right)>\sigma^{2}\left(R_{H}\right)
\end{aligned}
$$

where $\sigma^{2}\left(R_{U}\right)$ is the variance rate of the return under the no-hedge decision and $\sigma^{2}\left(R_{H}\right)$ is the variance of the rate of return under the hedge decision. The test statistic is

which will be accompanied by the variance reduction

$$
V R=\frac{\sigma^{2}\left(R_{U}\right)}{\sigma^{2}\left(R_{H}\right)} \geq F_{\alpha}(n-1, n-1)
$$

$$
V D=100\left[1-\frac{\sigma^{2}\left(R_{H}\right)}{\sigma^{2}\left(R_{U}\right)}\right]=100\left[1-\frac{1}{V R}\right]
$$

First-difference model using (OLS)

The conventional hedge ratio under OLS is estimated by

$$
\Delta p_{u, t}=\alpha+h \Delta p_{a, t}+\varepsilon_{t} .
$$

This OLS model is called 'conventional' as it uses historical data, and the $R^{2}$ obtained from the regression represents the effectiveness of the hedge. We use the OLS because of its simplicity, and because it is widely used among researchers. The OLS model can also be estimated using level data instead of first differences as

$$
p_{u, t}=\alpha+h p_{a, t}+\varepsilon_{t}
$$

First-difference model using Cochrance-Orcutt method with AR(1)

The Cochrance-Orcutt method overcomes the problem of serial correlation in the residuals - if it existed. This is because if we run a simple OLS estimation and there is serial correlation, our OLS will still provide the unbiased estimator but will not be the best linear unbiased efficient estimator (BLUE) (Brooks, 2014). In addition, the 
confidence interval and hypothesis testing become misleading, as they will depend on incorrect standard errors estimated from the OLS. This method consists of two iterative steps, which are (i) estimating first-order correlation $\tau$; and (ii) estimating the generalised least squares (GLS) equation using $\hat{\tau}$ (Studenmund, 2011; Hill et al., 2011). Suppose that there is an equation similar to Equation (5). First, we run a regression of lagged errors with $\operatorname{AR}(1)$

$$
\varepsilon_{t}=\tau \varepsilon_{t-1}+u_{t} \quad-1<\tau<1
$$

Then, the estimated $\hat{\tau}$ from Equation (7) is multiplied by Equation (5) and used in a lagged version of the equation as

$$
\hat{\tau} \Delta p_{u, t-1}=\hat{\tau} b_{0}+\hat{\tau} h \Delta p_{a, t-1}+\hat{\tau} \varepsilon_{t-1}
$$

Subtracting Equation (8) from Equation (5) we get

$$
\Delta p_{u, t}-\hat{\tau} \Delta p_{u, t-1}=\alpha(1-\hat{\tau})+h\left(\Delta p_{a, t}-\hat{\tau} \Delta p_{a, t-1}\right)+u_{t}
$$

or it can be written in this form:

$$
\Delta p_{u, t}^{*}=\alpha^{*}+h \Delta p_{a, t}^{*}+u_{t}^{*}
$$

The use of an autoregressive model means that the dependent variable is related to its lag value. Coffey et al. (2000) use the Cochrance-Orcutt method in estimating the hedge ratio for some grains that are used to feed livestock.

Maximum-likelihood method with an MA (1)

A moving-average process combines both the average of the current period's random error and the previous period's random error (Gujarati, 2003). It is used whenever serial correlation exists. The error process is

$$
\varepsilon_{t}=\theta u_{t-1}+u_{t}
$$

This model suggests that error term follows a first-order moving average, and this process is short-lived with no memory of previous levels.

First-difference model using instrumental variables (IV) with an AR (1)

Instrumental variable (IV) is also used to estimate the hedge ratio. Given that the OLS is based on the assumption that the independent variable and the error term are uncorrelated, this means that the independent variable is exogenous. However, if the covariance between the independent variable and the error term is not equal to zero, the independent variable becomes endogenous. According to Wooldridge (2009), there are three causes for endogeneity (i) omitted variables; (ii) error in the variables; and (iii) measurement error in the independent variable. As a result, OLS becomes unreliable, because the coefficient is biased and inconsistent. To solve this problem, IV is proposed. For example, if we have omitted a variable from the regression model, this omitted variable will definitely affect the error term, and if at the same time this omitted variable is correlated with $\Delta p_{a, t-1}$, OLS will be biased and inconsistent. Under IV, we add a new variable that is uncorrelated with the error term but is correlated with $\Delta p_{a, t-1}$. In this case the IV becomes consistent. The use of IV to estimate the hedge ratio of the returns of securities listed in the NYSE and the ASE was used by Scholes and Williams (1977).

First-difference model using a nonlinear quadratic specification

We also estimate the hedge ratio using a nonlinear regression first-difference model as

$$
\Delta p_{u, t}=\alpha+h \Delta p_{a, t}+\gamma \Delta p_{a, t}^{2}+\varepsilon_{t}
$$

where we have a linear parameter $\gamma$ and a squared term of the independent variable $p_{a, t}^{2}$. Such a model was proposed by Chow et al. (2000) in their study on the AUD, GBP, CAD, DEM, FRF, and JPY to capture the nonlinear relationship between spot and forward exchange rates.

\section{First-difference model using a linear error-correction model (ECM)}

Suppose that there is linear combination in the cointegration regression as in Equation (6)

$$
p_{u, t}=\alpha+h p_{a, t}+\varepsilon_{t}
$$

that is $p_{u, t}$ and $p_{a, t}$ to be cointegrated $\varepsilon_{t} \sim I(0)$ (Engle and Granger 1987). In other words, the residuals are stationary and the two series do not diverge too far from each other. (Note 5) This suggests that Equation (8) is misspecified, because there is a long-run or equilibrium relationship between the two variables. Therefore, it would be better to respecify the model using an ECM to take into account short-term dynamics as in

$$
\Delta p_{u, t}=\alpha+\sum_{i=1}^{n} \beta_{i} \Delta p_{u, t-i}+h \Delta p_{a, t}+\sum_{i=1}^{n} \gamma_{i} \Delta p_{a, t-i}+\theta \varepsilon_{t-1}+\zeta_{t}
$$


where $\gamma_{i}$ defines the short-term relationship between $\Delta p_{u, t}$ and $\Delta p_{a, t-i} ; \varepsilon_{t-1}$ is an error-correction term which is the lagged value of the empirical residual of a regression of $p_{u, t}$ on $p_{a, t}$ (which represents the long-term relationship or the cointegrating regression); $\theta$, which is the coefficient on the error-correction term, is a measure of the speed of adjustment to deviations from the long-run equilibrium condition. For a valid ECM, $\theta$ must be significantly negative. If $\varepsilon_{t-1}$ is positive, this means that $p_{u, t-1}$ is above the equilibrium; it is too high, and it should fall in the next period so that the equilibrium error is corrected. Lien and Luo (1993) use an ECM as in Equation (13) in estimating the hedge ratio for a number of foreign currencies and stock-index futures. In addition, Alexander (1999) uses as ECM as in Equation (13) to estimate the optimal hedge ratio for equity-index tracking and hedging of international-equity portfolios. The ECM was also used by Hatemi-J and Roca (2010) in their study on the US and UK equity markets.

\section{First-difference model using a nonlinear error-correction model (NECM)}

We have NECM with $\mathrm{A}(\mathrm{L})$ and $\mathrm{B}(\mathrm{L})$ which represent lag polynomials.

$$
\Delta p_{u, t}=A(L) \Delta p_{u, t-i}+B(L) \Delta p_{a, t}+\sum_{i=1}^{k} \gamma_{i} \varepsilon_{t-i}^{i}+\zeta_{t}
$$

This model - proposed by Escribano (1978) to model economic variables that have statistical properties differing from classical linear time series properties - was used empirically by Hendry and Eriscon (1991) to analyse the demand for money in the United Kingdom over the period 1878 to 1970. Chow et al. (2000) also used such a model to capture the nonlinear relationship between the spot and forward rates for a number of currencies.

\section{First-difference model using an autoregressive distributed lag ARDL $(1,1)$}

Autoregressive distributed lag (ARDL) uses a lagged value of both the dependent variable and the independent variable. According to Hill et al. (2011), the ARDL has an advantage in that it eliminates serial correlation in the errors. The hedge ratio is estimated using the following model:

$$
\Delta p_{u, t}=\sum_{i=1}^{m} \alpha_{i} \Delta p_{u, t-i}+\sum_{i=0}^{n} \beta_{i} \Delta p_{a, t-i}+\zeta_{t}
$$

where the hedge ratio is represented by the long-run coefficient $\beta_{0}$. The number of lagged $\mathrm{m}$ and $\mathrm{n}$ of the model is based on selection criteria such as the Akaike Information Criterion (AIC) and Schwarz Criterion (SC).

First-difference model using an autoregressive distributed lag ARDL $(1,1)$

Again, the ARDL in Equation (15) is used here, but the hedge ratio is differently calculated using an impact coefficient as

$$
h=\frac{\sum_{i=0}^{n} \beta_{i}}{1-\sum_{i=1}^{m} \alpha_{i}}
$$

This hedge ratio can also be called a long-run hedge ratio.

\section{Data and Empirical Results}

We use a sample of end-of-the-month data for the spot exchange rate and the one-month forward rate of the Kuwaiti dinar (KWD), Saudi riyal (SAR), Emirati dirham (AED), Bahraini dinar (BHD) and Qatari riyal (QAR) as base currencies against the US dollar (USD), British pound (GBP), Swiss franc (CHF), and Japanese yen (JPY). The data are obtained from Thomson Reuters' DataStream and the International Monetary Fund's International Financial Statistics CD-ROM for the period 1:2000 to 11:2011. We assign $x$ to the base currency, $y$ to the exposure currency and $z$ for a third currency that is a cross-currency. We assume a domestic firm in the GCC with payables of 100 in the foreign currency (exposure currency y). Table 2 summarises the sample data period for each currency, depending on availability (Note 6).

Table 2. Sample data period for each currency against the CHF, GBP, and JPY

\begin{tabular}{lcc}
\hline Base Currency $(x)$ & Period (End of the Month) & Number of Observations \\
\hline KWD & $1: 2000-11: 2011$ & 143 \\
SAR & $1: 2000-11: 2011$ & 143 \\
AED & $5: 2000-11: 2011$ & 139 \\
QAR & $7: 2004-11: 2011$ & 89 \\
BHD & $12: 2006-11: 2011$ & 60 \\
\hline
\end{tabular}

For the money-market hedging, the correlation between $\Delta s(x / y)$ and $\Delta \bar{f}(x / y)$ determines the effectiveness of money-market hedging, whereas the correlation between the exposure-currency exchange rate $\Delta s(x / y)$ and the third-currency exchange rate $\Delta s(x / z)$ determines the effectiveness of cross-currency hedging. 
Tables 3 to 13 present the results of estimating the hedge ratio using different econometric models for both money-market hedging and cross-currency hedging. They report goodness of fit, $t$ statistic, variance ratio (VR), and variance reduction (VD). (Note 7) Money-market hedging results (in Tables 3 to 7) show that a perfect hedge is obtained for all of the econometric models, as VD is almost equal to 99 percent. The results also show that a hedge ratio of 1 (naïve model) is obtained. (Note 8) Cross-currency hedging results (in Tables 8 to 12) show that different econometric models under cross-currency hedging produce a hedge ratio that is almost the same in each model, but neither close to unity nor significant in several currency combinations. Comparing the hedge ratio with money-market hedging, we notice that currency combinations under cross-currency hedging do not reduce the variance significantly (no perfect hedge). This is attributed either to no relationship or a weak relationship between the exposure-currency exchange rate $\Delta s(x / y)$ and the third-currency exchange rate $\Delta s(x / z)$.

On the other hand, the perfect hedge for all currency combinations achieved under money-market hedging is attributed to the strong relationship between the spot rate and the implicit forward rate. The results suggest that money-market hedging is preferred to cross-currency hedging. In addition, they suggest that the sophistication of the econometric models used to estimate the hedge ratio does not yield any difference compared with the simple OLS model. The results are approximately the same. The rest of the Tables and Figures are included at the end of this paper.

\section{Conclusion}

In this paper, we examined the effectiveness of different econometric models in minimising the variance of the hedge ratio for the GCC currencies under money-market hedging and cross-currency hedging. The aim of this examination was to determine whether different model specifications and estimation methods yield different effectiveness results. In other words, does the sophistication of the model improve the effectiveness of the hedge? Our results showed that these econometric models fail either to add value or to improve the effectiveness of the hedge. This implies that there is no need for a sophisticated econometric model to estimate the hedge ratio, because what matters is correlation.

Table 3. Money-market hedging-KWD

\begin{tabular}{|c|c|c|c|c|c|c|c|}
\hline & $x$ & $y$ & $R^{2}$ & $h$ & $t$ statistic & VR & $\mathrm{VD}(\%)$ \\
\hline \multicolumn{8}{|l|}{ OLS } \\
\hline & KWD & $\mathrm{CHF}$ & 0.997 & $1.019^{*}$ & 211.042 & $71.510^{*}$ & 98.602 \\
\hline & KWD & GBP & 0.987 & $1.056^{*}$ & 103.125 & $38.608^{*}$ & 97.410 \\
\hline & KWD & JPY & 0.987 & $1.046^{*}$ & 104.663 & $53.037^{*}$ & 98.115 \\
\hline \multicolumn{8}{|l|}{ Cochrance-Orcutt } \\
\hline & KWD & $\mathrm{CHF}$ & 0.986 & $1.005^{*}$ & 101.993 & $72.468^{*}$ & 98.620 \\
\hline & KWD & GBP & 0.977 & $0.998^{*}$ & 76.500 & $43.020 *$ & 97.676 \\
\hline & KWD & JPY & 0.984 & $1.000^{*}$ & 95.148 & $60.121 *$ & 98.337 \\
\hline \multicolumn{8}{|l|}{ MLE } \\
\hline & KWD & $\mathrm{CHF}$ & 0.986 & $1.004 *$ & 101.966 & $72.466^{*}$ & 98.620 \\
\hline & KWD & GBP & 0.977 & $0.998 *$ & 76.995 & $43.026^{*}$ & 97.675 \\
\hline & KWD & JPY & 0.984 & $0.999 *$ & 96.521 & $60.121 *$ & 98.336 \\
\hline \multicolumn{8}{|l|}{ IV } \\
\hline & KWD & $\mathrm{CHF}$ & 0.978 & $0.910^{*}$ & 14.144 & $44.038^{*}$ & 97.729 \\
\hline & KWD & GBP & 0.949 & $1.173^{*}$ & 1.173 & $19.638^{*}$ & 94.908 \\
\hline & KWD & JPY & 0.983 & $1.013 *$ & 19.840 & $59.464 *$ & 98.318 \\
\hline \multicolumn{8}{|l|}{ Quadratic } \\
\hline & KWD & $\mathrm{CHF}$ & 0.986 & $1.008 *$ & 93.720 & $72.457^{*}$ & 98.620 \\
\hline & KWD & GBP & 0.977 & $1.002 *$ & 75.539 & $43.073 *$ & 97.678 \\
\hline & KWD & JPY & 0.983 & $0.999 *$ & 90.864 & $60.122 *$ & 98.337 \\
\hline \multicolumn{8}{|l|}{ Linear ECM } \\
\hline & KWD & $\mathrm{CHF}$ & 0.987 & $1.008^{*}$ & 102.119 & $72.465 *$ & 98.620 \\
\hline & KWD & GBP & 0.979 & $0.998^{*}$ & 77.860 & $43.013 *$ & 97.675 \\
\hline & KWD & JPY & 0.985 & $1.006^{*}$ & 92.903 & $59.938^{*}$ & 98.332 \\
\hline \multicolumn{8}{|l|}{ Nonlinear ECM } \\
\hline & KWD & $\mathrm{CHF}$ & 0.988 & $1.007 *$ & 102.656 & $72.470^{*}$ & 98.620 \\
\hline
\end{tabular}




\begin{tabular}{|c|c|c|c|c|c|c|c|}
\hline & KWD & GBP & 0.979 & $0.996^{*}$ & 77.835 & $42.973^{*}$ & 97.673 \\
\hline & KWD & JPY & 0.985 & $1.001 *$ & 91.025 & $60.116^{*}$ & 98.337 \\
\hline \multicolumn{8}{|l|}{ ARDL } \\
\hline & KWD & $\mathrm{CHF}$ & 0.986 & $1.007 *$ & 98.757 & $72.469^{*}$ & 98.620 \\
\hline & KWD & GBP & 0.978 & $1.001 *$ & 76.930 & $43.067 *$ & 97.678 \\
\hline & KWD & JPY & 0.984 & $1.004 *$ & 90.540 & $60.036^{*}$ & 98.334 \\
\hline \multicolumn{8}{|l|}{ ARDL (long-run) } \\
\hline & KWD & $\mathrm{CHF}$ & 0.986 & $1.024 *$ & 43.385 & $70.945^{*}$ & 98.590 \\
\hline & KWD & GBP & 0.978 & $1.045^{*}$ & 41.678 & $40.226^{*}$ & 97.514 \\
\hline & KWD & JPY & 0.984 & $1.034 *$ & 42.650 & $56.134 *$ & 98.219 \\
\hline
\end{tabular}

* Significant at the $5 \%$ level.

\section{References}

Adler, M., \& Dumas, B. (1984). Exposure to Currency Risk: Definition and Measurement. Financial Management, 13, 41-50. http://dx.doi.org/10.2307/3665446

Aggarwal, R., \& Harper, J. (2010). Foreign Exchange Exposure of Domestic Corporations. Journal of International Money and Finance, 29, 1619-1636. http://dx.doi.org/10.1016/j.jimonfin.2010.05.003

Alexander, C. (1999). Optimal Hedging Using Cointegration. ICMA Centre, Reading University. Philosophical Transactions of The Royal Society Series A, 357, 2039-2058. http://dx.doi.org/10.1098/rsta.1999.0416

Alexander, C., \& Barbosa, A. (2007). Effectiveness of Minimum-Variance Hedging. Journal of Portfolio Management, 33, 46-59. http://dx.doi.org/10.3905/jpm.2007.674793

Alexander, C., Prokopczuk, M., \& Sumawong, A. (2013). The (De)merits of Minimum Variance Hedging: Application to the Crack Spread. Energy Economics, 36, 698-707. http://dx.doi.org/10.1016/j.eneco.2012.11.016

Al-Loughani, N., \& Moosa, I. (2000). Covered Interest Parity and the Relative Effectiveness of Forward and $\begin{array}{lllll}\text { Money Market Hedging. Applied Economics } & \text { Letters, }\end{array}$ http://dx.doi.org/10.1080/135048500416003

Baillie, R., \& Myers, R. (1991). Bivariate GARCH Estimation of the Optimal Commodity Futures Hedge. Journal of Applied Econometrics, 6, 109-124. http://dx.doi.org/10.1002/jae.3950060202

Benet, B. (1992). Hedging Period Length and Ex-ante Futures Hedging Effectiveness: The Case of Foreign Exchange Risk Cross Hedges. Journal of Futures Markets, 12, 163-175. http://dx.doi.org/10.1002/fut.3990120205

Brooks, C. (2014). Introductory Econometrics for Finance. Cambridge: Cambridge University Press.

Brooks, C., \& Chong, J. (2001). The Cross Currency Hedging Performance of Implied versus Statistical Forecasting Models. Journal of Futures Markets, 21, 1043-1069. http://dx.doi.org/10.1002/fut.2104

Brooks, C., Davies, R., \& Kim, S. (2006). Cross Hedging with Single Stock Futures. http://dx.doi.org/10.2139/ssrn.614004

Cecchetti, S. G., Cumby, R. E., \& Figlewski, S. (1988). Estimation of the Optimal Futures Hedge. Review of Economics and Statistics, 70, 623-30. http://dx.doi.org/10.2307/1935825

Chen, S., Lee, C., \& Shrestha, K. (2003). Futures Hedge Ratio: A Review. Quarterly Review of Economics and Finance, 43, 433-465. http://dx.doi.org/10.1016/S1062-9769(02)00191-6

Chou, W., Denis, K., \& Lee, C. (1996). Hedging with Nikkei Index Futures: The Conventional Model versus the Error Correction Model. Quarterly Review of Economics and Finance, 36, 495-505. http://dx.doi.org/10.1016/S1062-9769(96)90048-4

Chow, K., Broll, U., \& Wong, K. (2000). Hedging and Nonlinear Risk Exposure. Hong Kong Institute of Business Studies, Working Paper Series, Paper 30.

Coffey, B., Anderson, J., \& Parcell, J. (2000). Optimal Hedging Ratios and Hedging Risk for Grain by-Products. AAEA Annual Meeting, Tampa Bay, Florida, 28-31/2000.

Copeland, L., \& Zhu, Y. (2006). Hedging Effectiveness in the Index Futures Market. Working Paper E2006/10, Cardiff Business School. 
Ederington, L. (1979). The Hedging Performance of the New Futures Markets. Journal of Finance, 34, 157-170. http://dx.doi.org/10.1111/j.1540-6261.1979.tb02077.x

Engle, R., \& Granger, C. (1987). Cointegration and Error Correction: Representation, Estimation and Testing. Econometrica, 55, 251-276. http://dx.doi.org/10.2307/1913236

Escribano, A. (1978). Error Correction Systems: Nonlinear Adjustments to Linear Long-run Relationships. CORE Discussion Papers 8730.

Ghosh, A. (1993). Hedging with Stock Index Futures: Estimation and Forecasting with Error Correction Model. Journal of Futures Markets, 13, 743-752. http://dx.doi.org/10.1002/fut.3990130703

Ghosh, A. (1995). The Hedging Effectiveness of ECU Futures Contracts: Forecasting, Evidence from an Error Correction Model. Financial Review, 30, 567-581. http://dx.doi.org/10.1111/j.1540-6288.1995.tb00846.x

Ghosh, A. (1996). Cross Hedging Foreign Currency Risk: Empirical Evidence from an Error Correction Model. Review of Quantitative Finance and Accounting, 6, 223-231. http://dx.doi.org/10.1007/BF00245181

Graff, J., Schroder, T., Jones, R., \& Dhuyvetter, K. (1997). Cross Hedging Agricultural Commodities. Working Paper, Kansas State University, Cooperative Extension Service Bulletin, MF-2284.

Grant, D., \& Eaker, M. (1989). Complex Hedges: How Well Do They Work? Journal of Futures Markets, 9 , 15-27. http://dx.doi.org/10.1002/fut.3990090103

Gujarati, D. (2003). Basic Econometrics. New York: McGraw-Hill.

Hatemi, J. A., \& El-Khatib, Y. (2012). Stochastic Optimal Hedge Ratio: Theory and Evidence. Applied Economics Letters, 19, 699-703. http://dx.doi.org/10.1080/13504851.2011.572841

Hatemi, J. A., \& Roca, E. (2006). Calculating the Optimal Hedge Ratio: Constant, Time Varying and the Kalman Filter Approach. Applied Economics Letters, 13, 293-299. http://dx.doi.org/10.1080/13504850500365848

Hatemi, J. A., \& Roca, E. (2010). Estimating Optimal Hedge Ratio with Unknown Structural Breaks. Working Paper 2010:10, Griffith Business School.

Hendry, D., \& Eriscon, N. (1991). An Econometric Analysis of the UK Money Demand. In M. Milton Friedman, \& A. Schwartz (Eds.), Monetary Trends in the United States and the United Kingdom (pp. 45-101). Bank of England Panel of Academic Consultants, Paper 22.

Herbst, A., Kare, D., \& Marshall, J. (1993). A Time Varying, Convergence Adjusted, Minimum Risk Futures Hedge Ratio. Advances in Futures and Options Research, 6, 137-155.

Hill, J., \& Schneeweis, T. (1981). A Note on the Hedging Effectiveness of Foreign Currency Futures. Journal of Futures Markets, 1, 659-664. http://dx.doi.org/10.1002/fut.3990010408

Hill, R., Griffiths, W., \& Lim, G. (2011). Principles of Econometrics (4th ed.). MA: John Wiley and Sons.

Howard, C., \& D’Antonio, L. (1984). A Risk-Return Measure of Hedging Effectiveness. Journal of Financial and Quantitative Analysis, 1, 659-664. http://dx.doi.org/10.2307/2331004

Johnson, L. (1960). The Theory of Hedging and Speculation in Commodity Futures. Review of Economic Studies, 27, 139-151. http://dx.doi.org/10.2307/2296076

Jong, A., De Roon, F., \& Veld, C. (1997). Out of the Sample Hedging Effectiveness of Currency Futures for Alternative Models and Hedging Strategies. Journal of Futures Markets, 17, 817-837. http://dx.doi.org/10.1002/(SICI)1096-9934(199710)17:7<817::AID-FUT5>3.0.CO;2-Q

Jong, A., Roon, F., \& Veld, C. (1995). An Empirical Analysis of The Hedging Effectiveness of Currency Futures. Discussion Paper, Tilburg University, Center for Economic Research.

Junkus, J., \& Lee, C. (1985). Use of Three Index Futures in Hedging Decisions. Journal of Futures Markets, 5 , 201-222. http://dx.doi.org/10.1002/fut.3990050205

Kenourgios, D., Samitas, A., \& Drosos, P. (2008). Hedge Ratio Estimation and Hedging Effectiveness: The Case of the S\&P 500 Stock Index Futures Contract. International Journal of Risk Assessment and Management, 9, 121-134. http://dx.doi.org/10.1504/IJRAM.2008.019316

Khoury, S., \& Chan, K. (1988). Hedging Foreign Exchange Risk: Selecting the Optimal Tool. Midland Corporate Finance Journal, 5, 40-52.

Kolb, R., \& Okunev, J. (1992). An Empirical Evaluation of the Extended Mean-Gini Coefficient for Futures Hedging. Journal of Futures Markets, 12, 177-186. http://dx.doi.org/10.1002/fut.3990120206 
Kolb, R., \& Okunev, J. (1993). Utility Maximizing Hedge Ratios in The Extended Mean-Gini Framework. Journal of Futures Markets, 13, 597-609. http://dx.doi.org/10.1002/fut.3990130603

Kroner, K., \& Sultan, J. (1993). Time Varying Distributions and Dynamic Hedging with Foreign Currency Futures. Journal of Financial and Quantitative Analysis, 28, 535-551. http://dx.doi.org/10.2307/2331164

Lence, S. (1995). The Empirical Minimum Variance Hedge. American Journal of Agricultural Economics, 76, 94-104. http://dx.doi.org/10.2307/1243924

Lien, D. (1996). The Effect of the Cointegration Relationship on Futures Hedging: A Note. Journal of Futures Markets, 16 ,

773-780. http://dx.doi.org/10.1002/(SICI)1096-9934(199610)16:7<773::AID-FUT3>3.0.CO;2-L

Lien, D., \& Luo, X. (1993). Estimating Multiperiod Hedge Ratios in Cointegrated Markets. Journal of Futures Markets, 13, 909-920. http://dx.doi.org/10.1002/fut.3990130808

Lien, D., \& Tse, Y. (2002). Some Recent Developments in Futures Hedging. Journal of Economic Surveys, 16, 357-396. http://dx.doi.org/10.1111/1467-6419.00172

Lien, D., Tse, Y., \& Tsui, A. (2002). Evaluating the Hedging Performance of the Constant Correlation GARCH Models. Applied Financial Economics, 12, 791-798. http://dx.doi.org/10.1080/09603100110046045

Lindahl, M. (1991). Risk-Return Hedging Effectiveness Measures for Stock Index Futures. The Journal of Futures Markets, 11, 399-409. http://dx.doi.org/10.1002/fut.3990110402

Maharaj, E, Moosa, I, Jonathan, D., \& Silvapulle, P. (2008). Wavelet Estimation of Asymmetric Hedge Ratios: Does Econometric Sophistication Boost Hedging Effectiveness? International Journal of Business and Economics, 7, 213-230.

Malliaris, A., \& Urrutia, J. (1991). The Impact of the Lengths of Estimation Periods and Hedging Horizons on The Effectiveness of a Hedge: Evidence from Foreign Currency Futures. Journal of Futures Markets, 11, 271-289. http://dx.doi.org/10.1002/fut.3990110303

Moosa, I. (2003a). The Sensitivity of the Optimal Hedge Ratio to Model Specification. Finance Letters, 2, 32-37.

Moosa, I. (2003b). International Financial Operations: Arbitrage, Hedging, Speculation, Financing and Investment. London: Palgrave. http://dx.doi.org/10.1057/9781403946034

Moosa, I. (2011). The Failure of Financial Econometrics: Estimation of the Hedge Ratio as an Illustration. Journal of Financial Transformation, 31, 67-71.

Myers, R., \& Thompson, S. (1989). Generalized Optimal Hedge Ratio Estimation. American Journal of Agricultural Economics, 71, 858-867. http://dx.doi.org/10.2307/1242663

Park, S., \& Jei, S. (2010). Estimation and Hedging Effectiveness of Time Varying Hedge Ratio: Flexible Bivariate GARCH Approaches. Journal of Futures Markets, 30, 71-99. http://dx.doi.org/10.1002/fut.20401

Scholes, M., \& Williams, J. (1977). Estimating Betas from Nonsynchronous Data. Journal of Financial Economics, 5, 309-327. http://dx.doi.org/10.1016/0304-405X(77)90041-1

Schwab, B., \& Peter Lusztig, P. (1978). Foreign Exchange Risk through the Use of Third Currencies: Some Questions on Efficiency. Financial Management Journal, 7, 25-30. http://dx.doi.org/10.2307/3665007

Sephton, P. (1993). Hedging Wheat and Canola at the Winnipeg Commodity Exchange. Applied Financial Economics, 3, 67-72. http://dx.doi.org/10.1080/758527819

Shapiro, A. (2010). Multinational Financial Management (9th ed.). New Jersey: John Wiley and Sons, Inc.

Studenmund, A. (2011). Using Econometrics: A Practical Guide. Boston: Pearson Addison Wesley.

Stulz, R. (2003). Risk Management and Derivatives. Ohio: Thomson South-Western.

Wang, Y., Chongfeng, W., \& Yang, L. (2015). Hedging with Futures: Does Anything Beat the Naïve Hedging Strategy? Management Science, 60, 796-804. http://dx.doi.org/10.1287/mnsc.2014.2028

Wilson, W. (1983). Hedging Effectiveness of US Wheat Futures Markets. Review of Research in Futures Markets, 3, 64-67.

Witt, H., Schroder, T., \& Hayenga, M. (1987). Comparison of Analytical Approaches for Estimating Hedge Ratios for Agricultural Commodities. Journal of Futures Markets, 7, 135-146. 
http://dx.doi.org/10.1002/fut.3990070204

Wooldridge, J. (2009). Introductory Econometrics: A Modern Approach (4th ed.). Ohio: South-Western Cengage Learning.

\section{Notes}

Note 1. In principle, it is possible to obtain a perfect hedge if the prices of two positions are perfectly correlated and the optimal hedge ratio (in this case a hedge ratio of 1) is used. In practice firms are not entirely risk averse, in which case they do not use a hedge ratio of 1 , which means that the hedge is not perfect.

Note 2. Given that the hedge ratio equals $h=\frac{\operatorname{Cov}\left(R_{U}, R_{A}\right)}{\operatorname{Var}\left(R_{A}\right)}$, time-variant or invariant is related to $\operatorname{Cov}\left(R_{U}, R_{A}\right)$ and $\operatorname{Var}\left(R_{A}\right)$.

Note 3. We do not compare a static hedge ratio with a dynamic hedge ratio; instead, we examine different techniques for estimating the hedge ratio that range from conventional models to sophisticated ones.

Note 4. Brooks et al. (2006) argue that a naïve hedge ratio of 1 becomes optimal only if we have perfect correlation between spot and futures, and that it is constant over time.

Note 5. If there is a unit root and both series can be cointegrated.

Note 6. We encountered several limitations related to data availability. This problem is normal for researchers working with data for developing countries. For example, Oman is excluded from this study because of inaccurate exchange-rate data and the unavailability of interest rates. In addition, the sample period for each country in this study is not exactly the same because of a lack of interest-rate data for most of the countries at the time of collecting the data.

Note 7. According to Malliaris and Urrutia (1991), the $R^{2}$ obtained from the first-difference model can be used for the effectiveness of the hedge, because the $R^{2}$ will be equal to the hedge ratio; whereas, Lindahl (1991) shows that the Mean Absolute Difference (MAD) can be used for the effectiveness of the hedge for risk-minimising the portfolio. Moreover, Graff et al. (1997) show that the Root Mean Square Percentage Error (RMSPE) can be used for the effectiveness of the hedge. In this paper, we use $R^{2}, \mathrm{VR}$, and VD for the effectiveness of the hedge.

Note 8 . The naïve model assumes that the hedge ratio is always a negative one. This means taking an amount equal in value to the spot position, but in the opposite position to the financial derivative or asset (long AUD 1 and short AUD 1, or vice versa).

\section{Appendix}

Table 4. Money-market hedging-SAR

\begin{tabular}{|c|c|c|c|c|c|c|c|}
\hline & $x$ & $y$ & $R^{2}$ & $h$ & t statistic & VR & $\mathrm{VD}(\%)$ \\
\hline \multicolumn{8}{|l|}{ OLS } \\
\hline & SAR & $\mathrm{CHF}$ & 0.998 & $1.016^{*}$ & 256.430 & 145.068 & 99.311 \\
\hline & SAR & GBP & 0.994 & $1.028^{*}$ & 151.293 & 101.231 & 99.012 \\
\hline & SAR & JPY & 0.991 & $1.054^{*}$ & 127.611 & 99.477 & 98.995 \\
\hline \multicolumn{8}{|l|}{ Cochrance-Orcutt } \\
\hline & SAR & $\mathrm{CHF}$ & 0.994 & $0.994 *$ & 148.104 & $154.284^{*}$ & 99.352 \\
\hline & SAR & GBP & 0.991 & $1.007^{*}$ & 119.764 & $105.141^{*}$ & 99.049 \\
\hline & SAR & JPY & 0.993 & $1.012 *$ & 141.149 & $123.604^{*}$ & 99.191 \\
\hline \multicolumn{8}{|l|}{ MLE } \\
\hline & SAR & $\mathrm{CHF}$ & 0.993 & $0.993 *$ & 147.756 & $154.296^{*}$ & 99.351 \\
\hline & SAR & GBP & 0.990 & $1.007 *$ & 120.821 & $105.144^{*}$ & 99.048 \\
\hline & SAR & JPY & 0.992 & $1.011^{*}$ & 135.675 & $123.654^{*}$ & 99.191 \\
\hline \multicolumn{8}{|l|}{ IV } \\
\hline & SAR & $\mathrm{CHF}$ & 0.992 & $0.951 *$ & 27.876 & $119.543^{*}$ & 99.163 \\
\hline & SAR & GBP & 0.991 & $1.014^{*}$ & 36.071 & $104.832 *$ & 99.046 \\
\hline & SAR & JPY & 0.991 & $1.043^{*}$ & 27.768 & $108.983^{*}$ & 99.082 \\
\hline
\end{tabular}




\begin{tabular}{|c|c|c|c|c|c|c|c|}
\hline \multicolumn{8}{|l|}{ Quadratic } \\
\hline & SAR & $\mathrm{CHF}$ & 0.994 & $0.993^{*}$ & 145.976 & $154.271^{*}$ & 99.352 \\
\hline & SAR & GBP & 0.991 & $1.005^{*}$ & 120.704 & $105.034^{*}$ & 99.048 \\
\hline & SAR & JPY & 0.992 & $1.010^{*}$ & 130.819 & $123.684 *$ & 99.191 \\
\hline \multicolumn{8}{|c|}{ Linear ECM } \\
\hline & SAR & $\mathrm{CHF}$ & 0.994 & $0.998^{*}$ & 146.804 & $154.131 *$ & 99.351 \\
\hline & SAR & GBP & 0.991 & $1.008^{*}$ & 121.452 & $105.160 *$ & 99.049 \\
\hline & SAR & JPY & 0.993 & $1.016^{*}$ & 133.916 & $123.121^{*}$ & 99.188 \\
\hline \multicolumn{8}{|c|}{ Nonlinear ECM } \\
\hline & SAR & $\mathrm{CHF}$ & 0.994 & $0.998^{*}$ & 145.897 & $154.080^{*}$ & 99.351 \\
\hline & SAR & GBP & 0.991 & $1.008^{*}$ & 120.997 & $105.160 *$ & 99.049 \\
\hline & SAR & JPY & 0.993 & $1.016^{*}$ & 132.871 & $123.119^{*}$ & 99.188 \\
\hline \multicolumn{8}{|l|}{ ARDL } \\
\hline & SAR & $\mathrm{CHF}$ & 0.994 & $0.997 *$ & 148.744 & $154.240 *$ & 99.352 \\
\hline & SAR & GBP & 0.991 & $1.009^{*}$ & 118.434 & $105.162 *$ & 99.049 \\
\hline & SAR & JPY & 0.993 & $1.014^{*}$ & 138.986 & $123.354 *$ & 99.189 \\
\hline \multicolumn{8}{|c|}{ ARDL (long-run) } \\
\hline & SAR & $\mathrm{CHF}$ & 0.994 & $1.017^{*}$ & 61.623 & $143.097^{*}$ & 99.301 \\
\hline & SAR & GBP & 0.991 & $1.022^{*}$ & 70.324 & $103.431^{*}$ & 99.033 \\
\hline & SAR & JPY & 0.993 & $1.044^{*}$ & 39.187 & $108.018^{*}$ & 99.074 \\
\hline
\end{tabular}

* Significant at the 5\% level.

Table 5. Money-market hedging-AED

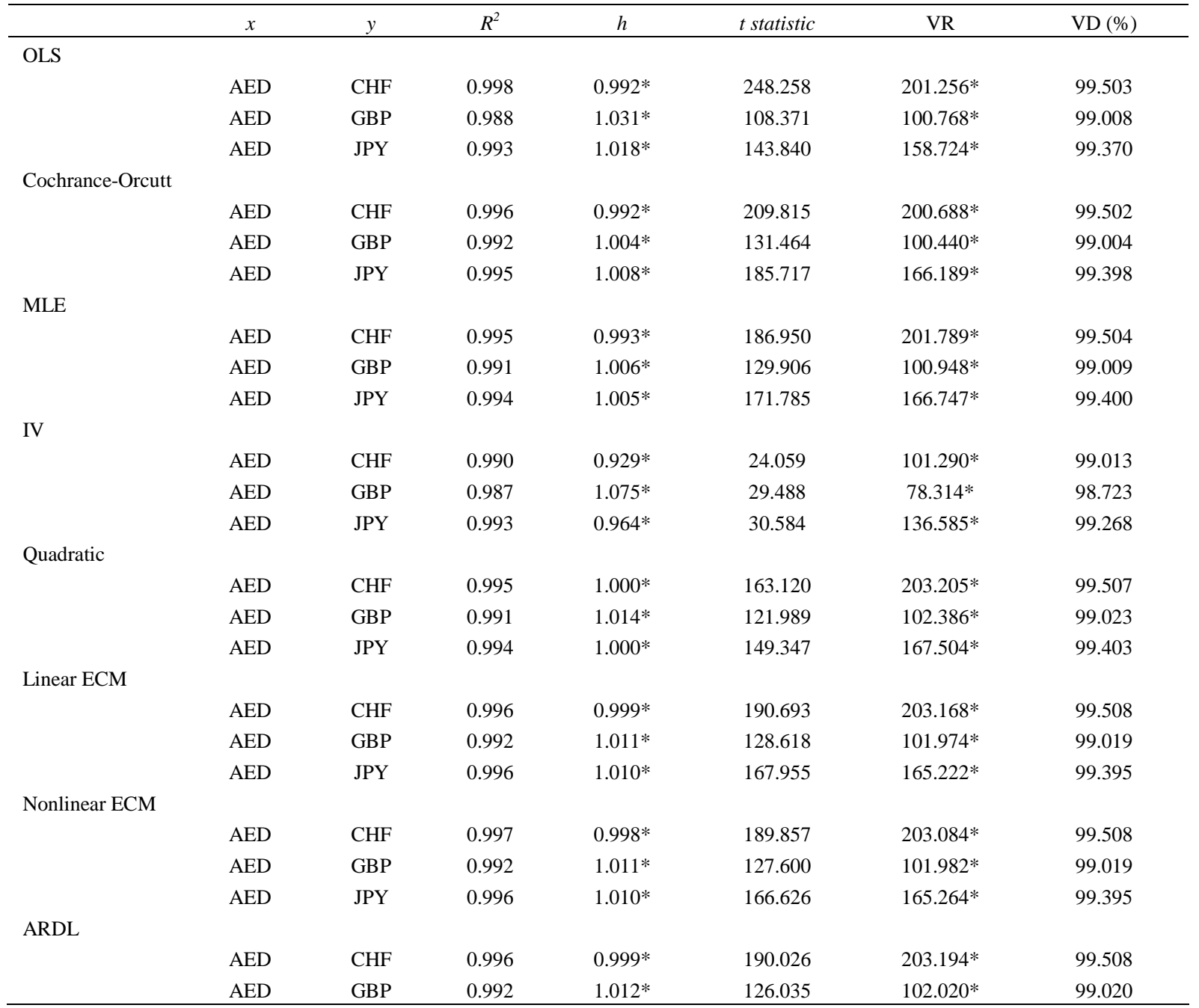




\begin{tabular}{llllllll}
\hline \multirow{2}{*}{ ARDL (long-run) } & AED & JPY & 0.996 & $1.009^{*}$ & 46.338 & $165.456^{*}$ & 99.396 \\
& & & & & & & \\
& AED & CHF & 0.996 & $1.036^{*}$ & 46.553 & $160.827^{*}$ & 99.378 \\
& AED & GBP & 0.992 & $1.049^{*}$ & 50.571 & $93.948^{*}$ & 98.936 \\
& AED & JPY & 0.996 & $1.036^{*}$ & 43.459 & $138.533^{*}$ & 99.278 \\
\hline
\end{tabular}

* Significant at the $5 \%$ level.

Table 6. Money-market hedging-QAR

\begin{tabular}{|c|c|c|c|c|c|c|c|}
\hline & $x$ & $y$ & $R^{2}$ & $h$ & $t$ statistic & VR & $\mathrm{VD}(\%)$ \\
\hline \multicolumn{8}{|l|}{ OLS } \\
\hline & QAR & $\mathrm{CHF}$ & 0.995 & $1.038 *$ & 135.890 & 40.069 & 97.504 \\
\hline & QAR & GBP & 0.986 & $1.092 *$ & 79.500 & 28.747 & 96.521 \\
\hline & QAR & JPY & 0.997 & $1.049^{*}$ & 168.700 & 19.140 & 94.775 \\
\hline \multicolumn{8}{|l|}{ Cochrance-Orcutt } \\
\hline & QAR & $\mathrm{CHF}$ & 0.978 & $0.999 *$ & 54.745 & $44.624 *$ & 97.759 \\
\hline & QAR & GBP & 0.971 & $1.019^{*}$ & 53.404 & $33.921 *$ & 97.052 \\
\hline & QAR & JPY & 0.955 & $0.979 *$ & 42.393 & $21.666^{*}$ & 95.384 \\
\hline \multicolumn{8}{|l|}{ MLE } \\
\hline & QAR & $\mathrm{CHF}$ & 0.978 & $1.004 *$ & 56.895 & $44.296^{*}$ & 97.742 \\
\hline & QAR & GBP & 0.970 & $1.020^{*}$ & 53.945 & $33.916^{*}$ & 97.051 \\
\hline & QAR & JPY & 0.955 & $0.987^{*}$ & 44.469 & $21.573 *$ & 95.364 \\
\hline \multicolumn{8}{|l|}{ IV } \\
\hline & QAR & $\mathrm{CHF}$ & 0.973 & $0.918^{*}$ & 12.845 & $37.203^{*}$ & 97.312 \\
\hline & QAR & GBP & 0.969 & $0.984 *$ & 19.855 & $32.784 *$ & 96.950 \\
\hline & QAR & JPY & 0.951 & $0.993 *$ & 10.101 & $21.477^{*}$ & 95.344 \\
\hline \multicolumn{8}{|l|}{ Quadratic } \\
\hline & QAR & $\mathrm{CHF}$ & 0.978 & $0.990 *$ & 61.231 & $44.951^{*}$ & 97.775 \\
\hline & QAR & GBP & 0.971 & $1.011^{*}$ & 52.187 & $33.873^{*}$ & 97.048 \\
\hline & QAR & JPY & 0.955 & $0.974 *$ & 42.690 & $21.690 *$ & 95.390 \\
\hline \multicolumn{8}{|l|}{ Linear ECM } \\
\hline & QAR & $\mathrm{CHF}$ & 0.980 & $0.999 *$ & 56.631 & $44.628^{*}$ & 97.759 \\
\hline & QAR & GBP & 0.974 & $1.009^{*}$ & 53.868 & $33.846^{*}$ & 97.045 \\
\hline & QAR & JPY & 0.961 & $0.984 *$ & 45.026 & $21.612 *$ & 95.373 \\
\hline \multicolumn{8}{|l|}{ Nonlinear ECM } \\
\hline & QAR & $\mathrm{CHF}$ & 0.981 & $1.005^{*}$ & 56.247 & $44.281 *$ & 97.742 \\
\hline & QAR & GBP & 0.975 & $1.001 *$ & 53.455 & $33.637^{*}$ & 97.027 \\
\hline & QAR & JPY & 0.967 & $0.987^{*}$ & 48.187 & $21.578^{*}$ & 95.366 \\
\hline \multicolumn{8}{|l|}{ ARDL } \\
\hline & QAR & $\mathrm{CHF}$ & 0.981 & $1.002 *$ & 57.432 & $44.487^{*}$ & 97.752 \\
\hline & QAR & GBP & 0.972 & $1.019^{*}$ & 50.944 & $33.923^{*}$ & 97.052 \\
\hline & QAR & JPY & 0.963 & $0.977 *$ & 46.338 & $21.675^{*}$ & 95.386 \\
\hline \multicolumn{8}{|l|}{ ARDL (long-run) } \\
\hline & QAR & $\mathrm{CHF}$ & 0.981 & $1.047^{*}$ & 50.116 & $38.562 *$ & 97.407 \\
\hline & QAR & GBP & 0.972 & $1.057 *$ & 43.999 & $32.346^{*}$ & 96.908 \\
\hline & QAR & JPY & 0.963 & $1.041^{*}$ & 43.459 & $19.616^{*}$ & 94.902 \\
\hline
\end{tabular}

* Significant at the 5\% level. 
Table 7. Money-market hedging-BHD

\begin{tabular}{|c|c|c|c|c|c|c|c|}
\hline & $x$ & $y$ & $R^{2}$ & $h$ & $t$ statistic & VR & $\mathrm{VD}(\%)$ \\
\hline \multicolumn{8}{|l|}{ OLS } \\
\hline & BHD & $\mathrm{CHF}$ & 0.998 & $1.025^{*}$ & 180.410 & $289.865^{*}$ & 99.655 \\
\hline & BHD & GBP & 0.996 & $1.061 *$ & 120.257 & $79.451 *$ & 98.741 \\
\hline & BHD & JPY & 0.999 & $1.002 *$ & 222.024 & $192.74 *$ & 98.998 \\
\hline \multicolumn{8}{|l|}{ Cochrance-Orcutt } \\
\hline & BHD & $\mathrm{CHF}$ & 0.996 & $1.016^{*}$ & 149.111 & $293.144 *$ & 99.659 \\
\hline & BHD & GBP & 0.990 & $0.999 *$ & 70.538 & $90.174 *$ & 98.891 \\
\hline & BHD & JPY & 0.992 & $1.010^{*}$ & 80.126 & $125.086^{*}$ & 99.201 \\
\hline \multicolumn{8}{|l|}{ MLE } \\
\hline & BHD & $\mathrm{CHF}$ & 0.996 & $1.016^{*}$ & 146.640 & $293.388^{*}$ & 99.659 \\
\hline & BHD & GBP & 0.989 & $1.003 *$ & 70.045 & 90.987* & 98.900 \\
\hline & BHD & JPY & 0.992 & $1.010 *$ & 80.300 & $125.091^{*}$ & 99.200 \\
\hline \multicolumn{8}{|l|}{ IV } \\
\hline & BHD & $\mathrm{CHF}$ & 0.995 & $0.977 *$ & 26.657 & $197.000 *$ & 99.492 \\
\hline & BHD & GBP & 0.988 & $1.049 *$ & 31.861 & $85.360 *$ & 98.828 \\
\hline & BHD & JPY & 0.991 & $0.984 *$ & 36.293 & $115.877^{*}$ & 99.137 \\
\hline \multicolumn{8}{|l|}{ Quadratic } \\
\hline & BHD & $\mathrm{CHF}$ & 0.997 & $1.019 *$ & 127.759 & $293.791 *$ & 99.660 \\
\hline & BHD & GBP & 0.990 & $1.011^{*}$ & 68.572 & $92.390 *$ & 98.918 \\
\hline & BHD & JPY & 0.992 & $1.000 *$ & 74.441 & $123.784 *$ & 99.192 \\
\hline \multicolumn{8}{|l|}{ Linear ECM } \\
\hline & BHD & $\mathrm{CHF}$ & 0.997 & $1.017 *$ & 137.840 & $293.581 *$ & 99.659 \\
\hline & BHD & GBP & 0.992 & $1.000 *$ & 74.810 & $90.257 *$ & 98.892 \\
\hline & BHD & JPY & 0.993 & $1.012 *$ & 83.084 & $124.967 *$ & 99.200 \\
\hline \multicolumn{8}{|l|}{ Nonlinear ECM } \\
\hline & BHD & $\mathrm{CHF}$ & 0.998 & $1.020 *$ & 133.879 & $293.710 *$ & 99.660 \\
\hline & BHD & GBP & 0.993 & $0.992 *$ & 74.230 & $87.415^{*}$ & 98.856 \\
\hline & BHD & JPY & 0.995 & $1.021 *$ & 94.216 & $123.070 *$ & 99.187 \\
\hline \multicolumn{8}{|l|}{ ARDL } \\
\hline & BHD & $\mathrm{CHF}$ & 0.997 & $1.021 *$ & 135.127 & $293.416^{*}$ & 99.659 \\
\hline & BHD & GBP & 0.991 & $1.007 *$ & 74.242 & $91.708^{*}$ & 98.910 \\
\hline & BHD & JPY & 0.992 & $1.011^{*}$ & 81.984 & $125.051^{*}$ & 99.200 \\
\hline \multicolumn{8}{|l|}{ ARDL (long-run) } \\
\hline & BHD & $\mathrm{CHF}$ & 0.997 & $1.060 *$ & 48.080 & $197.765^{*}$ & 99.494 \\
\hline & BHD & GBP & 0.991 & $1.055^{*}$ & 43.083 & $82.732 *$ & 98.791 \\
\hline & BHD & JPY & 0.992 & $1.043 *$ & 51.981 & $110.330^{*}$ & 99.094 \\
\hline
\end{tabular}

* Significant at the 5\% level.

Table 8. Cross-currency hedging-KWD

\begin{tabular}{|c|c|c|c|c|c|c|c|c|}
\hline & $x$ & $y$ & $z$ & $R^{2}$ & $h$ & $t$ statistic & VR & $\mathrm{VD}(\%)$ \\
\hline \multicolumn{9}{|l|}{ 1) OLS } \\
\hline & KWD & $\mathrm{CHF}$ & JPY & 0.068 & $0.291 *$ & 3.185 & 1.072 & 6.756 \\
\hline & KWD & $\mathrm{CHF}$ & GBP & 0.099 & $0.356^{*}$ & 3.931 & 1.110 & 9.941 \\
\hline & KWD & GBP & JPY & 0.001 & -0.020 & 0.001 & 1.000 & 0.000 \\
\hline & KWD & GBP & $\mathrm{CHF}$ & 0.163 & $0.324 *$ & 3.931 & 1.190 & 15.972 \\
\hline & KWD & JPY & $\mathrm{CHF}$ & 0.068 & $0.232 *$ & 3.185 & 1.072 & 6.756 \\
\hline & KWD & JPY & GBP & 0.000 & 0.000 & 0.001 & 1.000 & 0.000 \\
\hline \multicolumn{9}{|c|}{ 2) Cochrance-Orcutt } \\
\hline & KWD & $\mathrm{CHF}$ & JPY & 0.078 & $0.311 *$ & 3.372 & 1.072 & 6.725 \\
\hline & KWD & $\mathrm{CHF}$ & GBP & 0.175 & $0.512 *$ & 5.357 & 1.194 & 16.277 \\
\hline & KWD & GBP & JPY & 0.005 & -0.021 & -0.270 & 1.001 & 0.051 \\
\hline & KWD & GBP & $\mathrm{CHF}$ & 0.160 & $0.321 *$ & 5.128 & 1.194 & 16.282 \\
\hline & KWD & JPY & CHF & 0.078 & $0.248 *$ & 3.383 & 1.072 & 6.726 \\
\hline
\end{tabular}




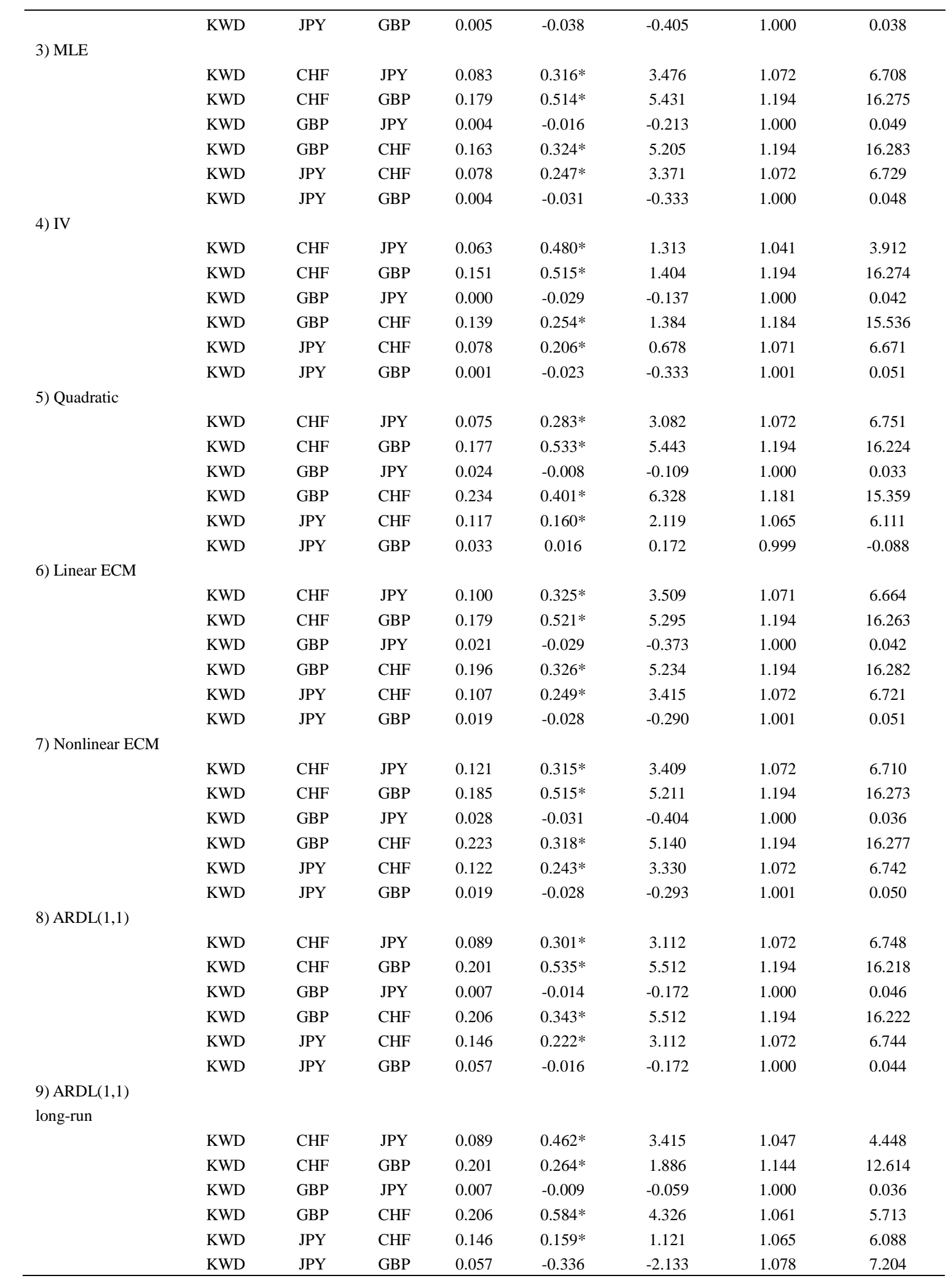

* Significant at the 5\% level. 
Table 9. Cross-currency hedging-SAR

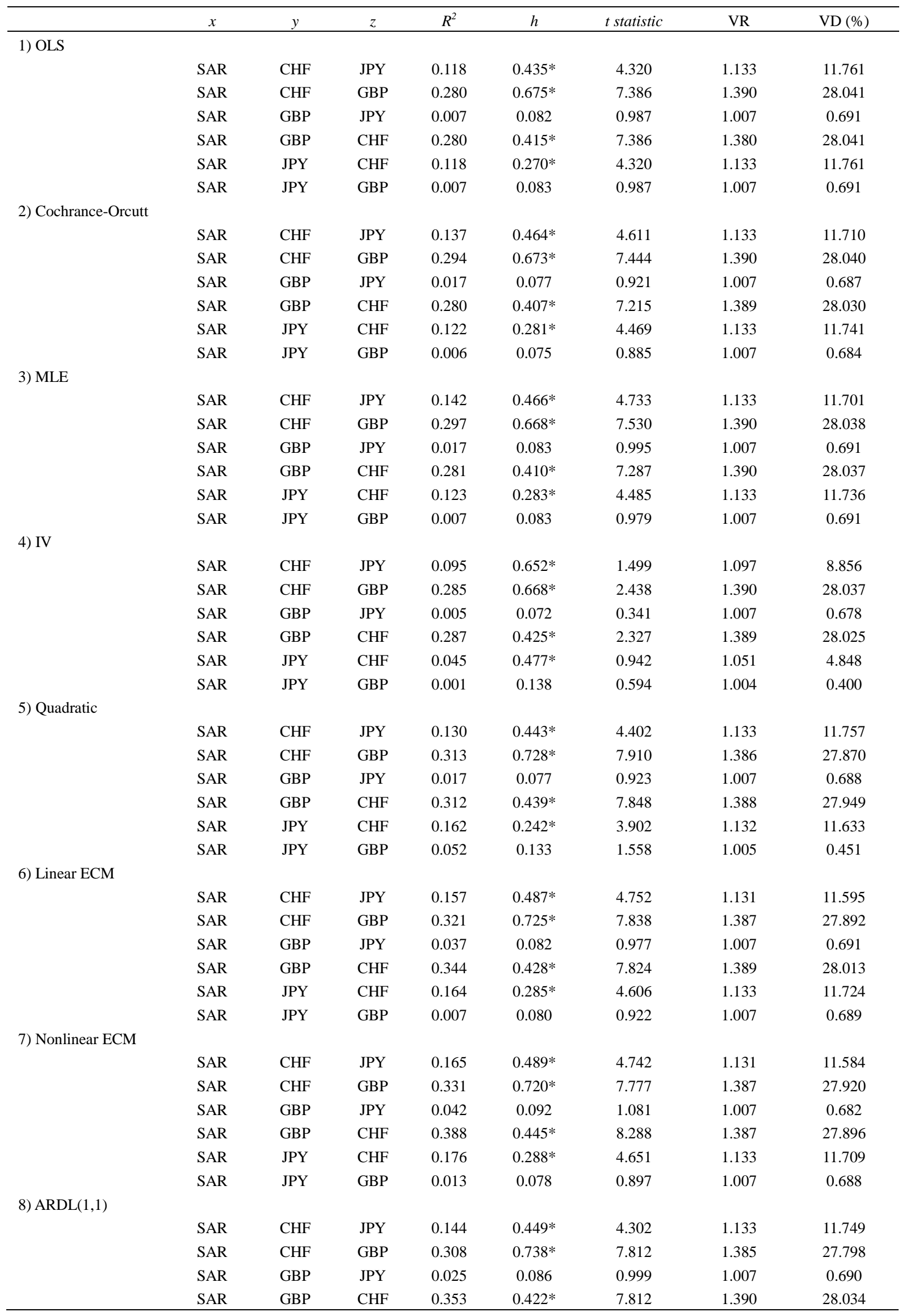




\begin{tabular}{lllllllll}
\hline & SAR & JPY & CHF & 0.159 & $0.269^{*}$ & 4.302 & 1.133 & 11.760 \\
& SAR & JPY & GBP & 0.028 & 0.085 & 0.999 & 1.007 & 0.690 \\
$\begin{array}{l}\text { 9) ARDL(1,1) } \\
\text { long-run }\end{array}$ & & & & & & & & \\
& & & & & & & & \\
& SAR & CHF & JPY & 0.144 & $0.608^{*}$ & 4.392 & 1.110 & 9.901 \\
& SAR & CHF & GBP & 0.308 & $0.444^{*}$ & 3.332 & 1.329 & 24.761 \\
& SAR & GBP & JPY & 0.025 & 0.081 & 0.460 & 1.007 & 0.690 \\
& SAR & GBP & CHF & 0.353 & $0.669^{*}$ & 5.057 & 1.213 & 17.587 \\
& SAR & JPY & CHF & 0.159 & $0.320^{*}$ & 2.734 & 1.128 & 11.361 \\
& SAR & JPY & GBP & 0.028 & -0.070 & -0.466 & 1.016 & 1.607 \\
\hline
\end{tabular}

* Significant at the $5 \%$ level.

Table 10. Cross-currency hedging-AED

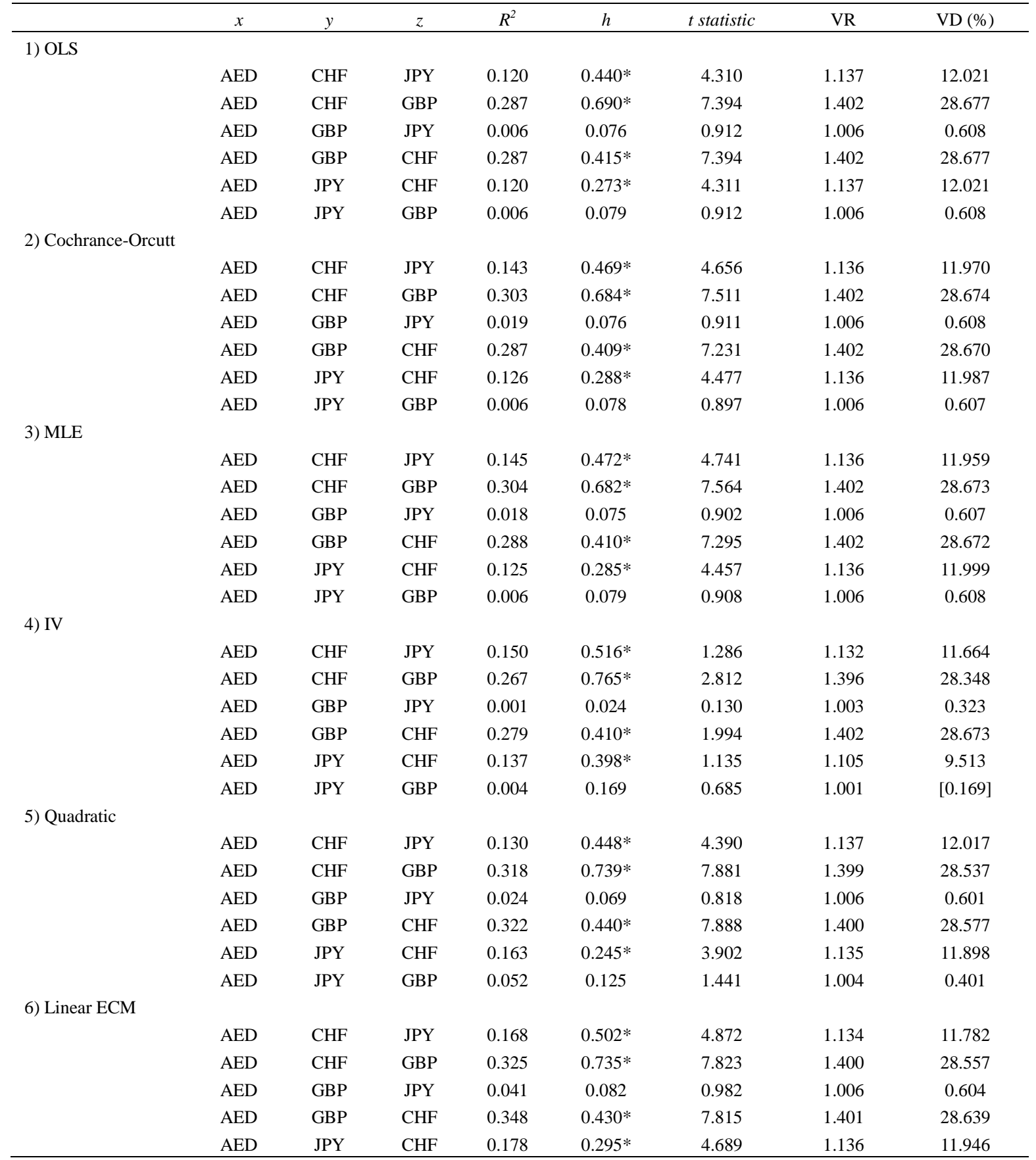




\begin{tabular}{|c|c|c|c|c|c|c|c|c|}
\hline & AED & JPY & GBP & 0.006 & 0.082 & 0.918 & 1.006 & 0.607 \\
\hline \multicolumn{9}{|l|}{ 7) Nonlinear ECM } \\
\hline & AED & $\mathrm{CHF}$ & JPY & 0.174 & $0.500 *$ & 4.799 & 1.134 & 11.796 \\
\hline & AED & $\mathrm{CHF}$ & GBP & 0.335 & $0.730 *$ & 7.752 & 1.400 & 28.583 \\
\hline & AED & GBP & JPY & 0.044 & 0.090 & 1.055 & 1.006 & 0.590 \\
\hline & AED & GBP & $\mathrm{CHF}$ & 0.392 & $0.447 *$ & 8.276 & 1.399 & 28.513 \\
\hline & AED & JPY & $\mathrm{CHF}$ & 0.196 & $0.295^{*}$ & 4.716 & 1.136 & 11.941 \\
\hline & AED & JPY & GBP & 0.014 & 0.080 & 0.887 & 1.006 & 0.608 \\
\hline \multicolumn{9}{|l|}{ 8) $\operatorname{ARDL}(1,1)$} \\
\hline & AED & $\mathrm{CHF}$ & JPY & 0.142 & $0.449 *$ & 4.280 & 1.137 & 12.016 \\
\hline & AED & $\mathrm{CHF}$ & GBP & 0.313 & $0.749 *$ & 7.832 & 1.398 & 28.475 \\
\hline & AED & GBP & JPY & 0.026 & 0.087 & 1.001 & 1.006 & 0.598 \\
\hline & AED & GBP & $\mathrm{CHF}$ & 0.357 & $0.426^{*}$ & 7.832 & 1.402 & 28.658 \\
\hline & AED & JPY & $\mathrm{CHF}$ & 0.157 & $0.273^{*}$ & 4.280 & 1.137 & 12.021 \\
\hline & AED & JPY & GBP & 0.031 & 0.088 & 1.001 & 1.006 & 0.601 \\
\hline \multicolumn{9}{|l|}{ 9) $\operatorname{ARDL}(1,1)$} \\
\hline \multicolumn{9}{|l|}{ long-run } \\
\hline & AED & $\mathrm{CHF}$ & JPY & 0.142 & $0.611^{*}$ & 4.362 & 1.114 & 10.204 \\
\hline & AED & $\mathrm{CHF}$ & GBP & 0.313 & $0.463^{*}$ & 3.402 & 1.343 & 25.555 \\
\hline & AED & GBP & JPY & 0.026 & 0.097 & 0.547 & 1.006 & 0.564 \\
\hline & AED & GBP & $\mathrm{CHF}$ & 0.357 & $0.660 *$ & 5.015 & 1.230 & 18.725 \\
\hline & AED & JPY & $\mathrm{CHF}$ & 0.157 & $0.336^{*}$ & 2.876 & 1.129 & 11.389 \\
\hline & AED & JPY & GBP & 0.031 & -0.079 & -0.517 & 1.018 & 1.779 \\
\hline
\end{tabular}

* Significant at the 5\% level, [ ] inverted.

Table 11. Cross-currency hedging-QAR

\begin{tabular}{|c|c|c|c|c|c|c|c|c|}
\hline & $x$ & $y$ & $z$ & $R^{2}$ & $h$ & t statistic & VR & $\mathrm{VD}(\%)$ \\
\hline \multicolumn{9}{|l|}{ 1) OLS } \\
\hline & QAR & $\mathrm{CHF}$ & JPY & 0.129 & $0.495^{*}$ & 3.568 & 1.148 & 12.895 \\
\hline & QAR & $\mathrm{CHF}$ & GBP & 0.232 & $0.622 *$ & 5.102 & 1.303 & 23.241 \\
\hline & QAR & GBP & JPY & 0.001 & 0.035 & 0.301 & 1.001 & 0.105 \\
\hline & QAR & GBP & CHF & 0.232 & $0.373^{*}$ & 5.102 & 1.303 & 23.241 \\
\hline & QAR & JPY & $\mathrm{CHF}$ & 0.119 & $0.071^{*}$ & 3.412 & 1.135 & 11.925 \\
\hline & QAR & JPY & GBP & 0.001 & 0.030 & 0.301 & 1.001 & 0.105 \\
\hline \multicolumn{9}{|c|}{ 2) Cochrance-Orcutt } \\
\hline & QAR & $\mathrm{CHF}$ & JPY & 0.163 & $0.521^{*}$ & 3.813 & 1.148 & 12.860 \\
\hline & QAR & $\mathrm{CHF}$ & GBP & 0.264 & $0.611^{*}$ & 5.288 & 1.303 & 23.233 \\
\hline & QAR & GBP & JPY & 0.033 & 0.079 & 0.698 & 1.000 & {$[0.059]$} \\
\hline & QAR & GBP & $\mathrm{CHF}$ & 0.243 & $0.353^{*}$ & 4.913 & 1.302 & 23.174 \\
\hline & QAR & JPY & CHF & 0.135 & $0.271^{*}$ & 3.652 & 1.148 & 12.876 \\
\hline & QAR & JPY & GBP & 0.001 & 0.029 & 0.285 & 1.001 & 0.105 \\
\hline \multicolumn{9}{|l|}{ 3) MLE } \\
\hline & QAR & CHF & JPY & 0.164 & $0.515^{*}$ & 3.832 & 1.148 & 12.874 \\
\hline & QAR & $\mathrm{CHF}$ & GBP & 0.264 & $0.601^{*}$ & 5.315 & 1.302 & 23.214 \\
\hline & QAR & GBP & JPY & 0.026 & 0.066 & 0.584 & 1.000 & 0.021 \\
\hline & QAR & GBP & CHF & 0.239 & $0.358^{*}$ & 4.960 & 1.302 & 23.203 \\
\hline & QAR & JPY & $\mathrm{CHF}$ & 0.134 & $0.270^{*}$ & 3.648 & 1.148 & 12.880 \\
\hline & QAR & JPY & GBP & 0.001 & 0.027 & 0.268 & 1.001 & 0.104 \\
\hline \multicolumn{9}{|l|}{ 4) IV } \\
\hline & QAR & $\mathrm{CHF}$ & JPY & 0.123 & $0.439^{*}$ & 0.809 & 1.146 & 12.734 \\
\hline & QAR & $\mathrm{CHF}$ & GBP & 0.205 & $0.700^{*}$ & 2.417 & 1.297 & 22.876 \\
\hline & QAR & GBP & JPY & 0.001 & 0.027 & 0.148 & 1.001 & 0.101 \\
\hline & QAR & GBP & $\mathrm{CHF}$ & 0.230 & $0.362 *$ & 1.463 & 1.302 & 23.218 \\
\hline & QAR & JPY & $\mathrm{CHF}$ & 0.111 & $0.284^{*}$ & 1.002 & 1.147 & 12.788 \\
\hline & QAR & JPY & GBP & 0.001 & 0.024 & 0.148 & 1.001 & 0.100 \\
\hline
\end{tabular}




\begin{tabular}{|c|c|c|c|c|c|c|c|c|}
\hline \multicolumn{9}{|l|}{ 5) Quadratic } \\
\hline & QAR & $\mathrm{CHF}$ & JPY & 0.142 & $0.496^{*}$ & 3.579 & 1.148 & 12.895 \\
\hline & QAR & $\mathrm{CHF}$ & GBP & 0.252 & $0.682^{*}$ & 5.355 & 1.299 & 23.030 \\
\hline & QAR & GBP & JPY & 0.047 & 0.034 & 0.298 & 1.001 & 0.105 \\
\hline & QAR & GBP & $\mathrm{CHF}$ & 0.294 & $0.392 *$ & 5.521 & 1.302 & 23.186 \\
\hline & QAR & JPY & $\mathrm{CHF}$ & 0.190 & $0.244^{*}$ & 3.425 & 1.147 & 12.841 \\
\hline & QAR & JPY & GBP & 0.053 & 0.100 & 0.957 & 1.004 & [0.436] \\
\hline \multicolumn{9}{|c|}{ 6) Linear ECM } \\
\hline & QAR & $\mathrm{CHF}$ & JPY & 0.221 & $0.554^{*}$ & 4.070 & 1.146 & 12.714 \\
\hline & QAR & $\mathrm{CHF}$ & GBP & 0.289 & $0.669^{*}$ & 5.338 & 1.301 & 23.109 \\
\hline & QAR & GBP & JPY & 0.093 & 0.046 & 0.402 & 1.001 & 0.095 \\
\hline & QAR & GBP & $\mathrm{CHF}$ & 0.317 & $0.386^{*}$ & 5.360 & 1.302 & 23.213 \\
\hline & QAR & JPY & $\mathrm{CHF}$ & 0.180 & $0.297^{*}$ & 3.996 & 1.145 & 12.638 \\
\hline & QAR & JPY & GBP & 0.019 & 0.046 & 0.432 & 1.001 & 0.078 \\
\hline \multicolumn{9}{|c|}{ 7) Nonlinear ECM } \\
\hline & QAR & $\mathrm{CHF}$ & JPY & 0.285 & $0.565^{*}$ & 4.272 & 1.145 & 12.638 \\
\hline & QAR & $\mathrm{CHF}$ & GBP & 0.335 & $0.641^{*}$ & 5.192 & 1.302 & 23.219 \\
\hline & QAR & GBP & JPY & 0.107 & 0.049 & 0.431 & 1.001 & 0.087 \\
\hline & QAR & GBP & $\mathrm{CHF}$ & 0.328 & $0.390^{*}$ & 5.359 & 1.302 & 23.194 \\
\hline & QAR & JPY & $\mathrm{CHF}$ & 0.211 & $0.326^{*}$ & 4.306 & 1.137 & 12.075 \\
\hline & QAR & JPY & GBP & 0.024 & 0.056 & 0.517 & 1.000 & 0.028 \\
\hline \multicolumn{9}{|l|}{ 8) $\operatorname{ARDL}(1,1)$} \\
\hline & QAR & $\mathrm{CHF}$ & JPY & 0.174 & $0.515^{*}$ & 3.616 & 1.148 & 12.874 \\
\hline & QAR & $\mathrm{CHF}$ & GBP & 0.285 & $0.698^{*}$ & 5.574 & 1.297 & 22.900 \\
\hline & QAR & GBP & JPY & 0.060 & 0.078 & 0.671 & 1.000 & {$[0.061]$} \\
\hline & QAR & GBP & $\mathrm{CHF}$ & 0.321 & $0.397 *$ & 5.574 & 1.301 & 23.145 \\
\hline & QAR & JPY & $\mathrm{CHF}$ & 0.173 & $0.270^{*}$ & 3.616 & 1.148 & 12.879 \\
\hline & QAR & JPY & GBP & 0.029 & 0.071 & 0.671 & 1.000 & {$[0.078]$} \\
\hline \multicolumn{9}{|l|}{ 9) $\operatorname{ARDL}(1,1)$} \\
\hline \multicolumn{9}{|l|}{ long-run } \\
\hline & QAR & $\mathrm{CHF}$ & JPY & 0.174 & $0.608^{*}$ & 3.314 & 1.139 & 12.217 \\
\hline & QAR & $\mathrm{CHF}$ & GBP & 0.285 & $0.374 *$ & 2.426 & 1.243 & 19.553 \\
\hline & QAR & GBP & JPY & 0.060 & -0.109 & -0.404 & 1.017 & 1.670 \\
\hline & QAR & GBP & $\mathrm{CHF}$ & 0.321 & $0.727 *$ & 3.568 & 1.024 & 2.380 \\
\hline & QAR & JPY & $\mathrm{CHF}$ & 0.173 & $0.302^{*}$ & 1.951 & 1.144 & 12.569 \\
\hline & QAR & JPY & GBP & 0.029 & -0.195 & -1.145 & 1.057 & 5.369 \\
\hline
\end{tabular}

* Significant at the $5 \%$ level, [ ] inverted.

Table 12. Cross-currency hedging-BHD

\begin{tabular}{|c|c|c|c|c|c|c|c|c|}
\hline & $x$ & $y$ & $z$ & $R^{2}$ & $h$ & $t$ statistic & VR & $\mathrm{VD}(\%)$ \\
\hline \multicolumn{9}{|l|}{ 1) OLS } \\
\hline & BHD & $\mathrm{CHF}$ & JPY & 0.053 & $0.436^{*}$ & 1.777 & 1.110 & 5.252 \\
\hline & BHD & $\mathrm{CHF}$ & GBP & 0.160 & $0.530 *$ & 3.291 & 1.190 & 15.970 \\
\hline & BHD & GBP & JPY & 0.039 & -0.120 & -1.515 & 1.010 & 3.874 \\
\hline & BHD & GBP & $\mathrm{CHF}$ & 0.160 & $0.300 *$ & 3.291 & 1.190 & 15.970 \\
\hline & BHD & JPY & $\mathrm{CHF}$ & 0.053 & $0.135 *$ & 1.777 & 1.055 & 5.252 \\
\hline & BHD & JPY & GBP & 0.039 & -0.154 & -1.515 & 1.040 & 3.874 \\
\hline \multicolumn{9}{|c|}{ 2) Cochrance-Orcutt } \\
\hline & BHD & $\mathrm{CHF}$ & JPY & 0.084 & $0.362 *$ & 1.716 & 1.055 & 5.229 \\
\hline & BHD & $\mathrm{CHF}$ & GBP & 0.216 & $0.527 *$ & 3.587 & 1.190 & 15.968 \\
\hline & BHD & GBP & JPY & 0.073 & -0.215 & -1.262 & 1.039 & 3.799 \\
\hline & BHD & GBP & $\mathrm{CHF}$ & 0.182 & $0.270 *$ & 3.052 & 1.188 & 15.801 \\
\hline & BHD & JPY & $\mathrm{CHF}$ & 0.072 & $0.116^{*}$ & 1.598 & 1.054 & 5.147 \\
\hline & BHD & JPY & GBP & 0.058 & -0.136 & -1.314 & 1.040 & 3.820 \\
\hline \multicolumn{9}{|l|}{ 3) MLE } \\
\hline & BHD & $\mathrm{CHF}$ & JPY & 0.093 & $0.378^{*}$ & 1.854 & 1.055 & 5.249 \\
\hline
\end{tabular}




\begin{tabular}{|c|c|c|c|c|c|c|c|c|}
\hline & BHD & CHF & GBP & 0.221 & $0.517 *$ & 3.724 & 1.190 & 15.958 \\
\hline & BHD & GBP & JPY & 0.067 & -0.225 & -1.353 & 1.040 & 3.834 \\
\hline & BHD & GBP & $\mathrm{CHF}$ & 0.174 & $0.276^{*}$ & 3.096 & 1.188 & 15.859 \\
\hline & BHD & JPY & $\mathrm{CHF}$ & 0.074 & $0.128 *$ & 1.730 & 1.055 & 5.235 \\
\hline & BHD & JPY & GBP & 0.056 & -0.143 & -1.372 & 1.040 & 3.853 \\
\hline \multicolumn{9}{|l|}{ 4) IV } \\
\hline & BHD & CHF & JPY & 0.048 & $0.399 *$ & 0.939 & 1.055 & 5.247 \\
\hline & BHD & $\mathrm{CHF}$ & GBP & 0.150 & $0.687 *$ & 2.026 & 1.171 & 14.591 \\
\hline & BHD & GBP & JPY & 0.035 & -0.290 & -0.705 & 1.039 & 3.776 \\
\hline & BHD & GBP & $\mathrm{CHF}$ & 0.158 & $0.348^{*}$ & 1.555 & 1.184 & 15.572 \\
\hline & BHD & JPY & $\mathrm{CHF}$ & 0.044 & $0.177 *$ & 1.004 & 1.050 & 4.751 \\
\hline & BHD & JPY & GBP & 0.048 & -0.168 & -0.989 & 1.040 & 3.846 \\
\hline \multicolumn{9}{|l|}{ 5) Quadratic } \\
\hline & BHD & CHF & JPY & 0.071 & $0.245^{*}$ & 0.955 & 1.048 & 4.542 \\
\hline & BHD & $\mathrm{CHF}$ & GBP & 0.171 & $0.588^{*}$ & 3.370 & 1.187 & 15.782 \\
\hline & BHD & GBP & JPY & 0.117 & -0.029 & -0.155 & 1.009 & 0.852 \\
\hline & BHD & GBP & $\mathrm{CHF}$ & 0.231 & $0.316^{*}$ & 3.570 & 1.189 & 15.930 \\
\hline & BHD & JPY & $\mathrm{CHF}$ & 0.104 & $0.126^{*}$ & 1.672 & 1.055 & 5.223 \\
\hline & BHD & JPY & GBP & 0.092 & -0.080 & -0.743 & 1.031 & 2.979 \\
\hline \multicolumn{9}{|l|}{ 6) Linear ECM } \\
\hline & BHD & CHF & JPY & 0.170 & $0.473 *$ & 2.160 & 1.045 & 4.289 \\
\hline & BHD & $\mathrm{CHF}$ & GBP & 0.256 & $0.590 *$ & 3.600 & 1.187 & 15.771 \\
\hline & BHD & GBP & JPY & 0.127 & -0.234 & -1.384 & 1.040 & 3.858 \\
\hline & BHD & GBP & $\mathrm{CHF}$ & 0.286 & $0.329 *$ & 3.660 & 1.188 & 15.832 \\
\hline & BHD & JPY & $\mathrm{CHF}$ & 0.134 & $0.171 *$ & 2.205 & 1.052 & 4.900 \\
\hline & BHD & JPY & GBP & 0.080 & -0.148 & -1.401 & 1.040 & 3.867 \\
\hline \multicolumn{9}{|l|}{ 7) Nonlinear ECM } \\
\hline & BHD & CHF & JPY & 0.216 & $0.515^{*}$ & 2.354 & 1.049 & 4.682 \\
\hline & BHD & $\mathrm{CHF}$ & GBP & 0.329 & $0.537 *$ & 3.348 & 1.190 & 15.968 \\
\hline & BHD & GBP & JPY & 0.224 & -0.221 & -1.330 & 1.040 & 3.820 \\
\hline & BHD & GBP & $\mathrm{CHF}$ & 0.303 & $0.321 *$ & 3.534 & 1.189 & 15.897 \\
\hline & BHD & JPY & $\mathrm{CHF}$ & 0.170 & $0.197 *$ & 2.486 & 1.044 & 4.188 \\
\hline & BHD & JPY & GBP & 0.081 & -0.140 & -1.235 & 1.040 & 3.841 \\
\hline \multicolumn{9}{|l|}{ 8) $\operatorname{ARDL}(1,1)$} \\
\hline & BHD & $\mathrm{CHF}$ & JPY & 0.119 & $0.446^{*}$ & 2.005 & 1.054 & 5.132 \\
\hline & BHD & CHF & GBP & 0.207 & $0.609 *$ & 3.563 & 1.185 & 15.624 \\
\hline & BHD & GBP & JPY & 0.102 & -0.186 & -1.081 & 1.038 & 3.621 \\
\hline & BHD & GBP & $\mathrm{CHF}$ & 0.267 & $0.322 *$ & 3.563 & 1.189 & 15.889 \\
\hline & BHD & JPY & $\mathrm{CHF}$ & 0.066 & $0.161 *$ & 2.005 & 1.053 & 5.068 \\
\hline & BHD & JPY & GBP & 0.044 & -0.118 & -1.081 & 1.038 & 3.657 \\
\hline \multirow{2}{*}{\multicolumn{9}{|c|}{$\begin{array}{l}\text { 9) } \operatorname{ARDL}(1,1) \\
\text { long-run }\end{array}$}} \\
\hline & & & & & & & & \\
\hline & BHD & $\mathrm{CHF}$ & JPY & 0.119 & $0.460 *$ & 1.938 & 1.053 & 5.069 \\
\hline & BHD & CHF & GBP & 0.207 & $0.308 *$ & 1.627 & 1.152 & 13.158 \\
\hline & BHD & GBP & JPY & 0.102 & -0.452 & -1.377 & 1.014 & 1.373 \\
\hline & BHD & GBP & $\mathrm{CHF}$ & 0.267 & $0.690 *$ & 2.382 & 1.107 & 9.655 \\
\hline & BHD & JPY & $\mathrm{CHF}$ & 0.066 & $0.375^{*}$ & 1.763 & 1.111 & 10.006 \\
\hline & BHD & JPY & GBP & 0.044 & -0.332 & -1.628 & 1.012 & 1.175 \\
\hline
\end{tabular}

* Significant at the $5 \%$ level.

\section{Copyrights}

Copyright for this article is retained by the author(s), with first publication rights granted to the journal.

This is an open-access article distributed under the terms and conditions of the Creative Commons Attribution license (http://creativecommons.org/licenses/by/3.0/). 